Tér és Társadalom 17. évf. 2003/2. 13-35. p.

\title{
MULTIETNICITÁS ÉS AZ EURÓPA-ESZME ${ }^{1}$
}

\author{
(Multiethnicity and the Idea of Europe)
}

\section{ASH AMIN}

Kulcsszavak:

Európa-eszme multikulturalizmus kulturálispluralizmus különbözöség állampolgár bevándorló hovatartozás EU-szintü jogok

A tanulmány az Európa-eszme jelentését és relevanciáját értékeli egy multikulturális, a nem európai gyökerỉek jelenlétéböl és szokásaiból egyre többet meritó kontinens kontextusában. A kirekesztônek és múltba nézönek itélt klasszikus Európa-eszme kritikáját adva egy alternativ Európa-eszme megalkotására is kísérletet tesz. Ennek alapja a migrációs térként érzékelt Európához tartozás különleges étosza, nem pedig az európainak nevezett embercsoport tovább élö kulturális értékei. Az egységet egalitáriánus politikai elvekkel biztosítja, mint a kulturális pluralizmust és különbözöséget egyszerre támogató és összekötö EU-szintü jogok. Olyan demokratikus vitalitást nyújt, melyben nincs sem eredet-, sem célmítosz, csak a polemizáló köznép iránti elkötelezettség.

„Az európai romanticizmus ... az a hagyomány, amellyel ritkán néznek szembe. Az a feltételezés él, hogy a folyamatosság és a közösség értékei, a hagyomány és a hagyomány átadása olyan értékek, amelyeket dicsỏíteni és védelmezni kell. Ezek az értékek erösítenek meg bennünket eredetiségünkben. ... De nem maradi és reakciós mítosz-e ez, amelyet mi, európaiak leszármazottai mondogatunk magunknak, hogy központiságunkba kapaszkodhassunk, amikor meg akarjuk érteni, mit jelent az otthon? Miközben máshol a világban arra kényszerülnek, hogy elfogadják a változásokat és a folytonosság megszakításait, addig egyetemes értékként ôrzik a hagyomány folytonosságát mindazok, akiknek hatalmukban áll meghatározni, mi az 'egyetemes' ". (lain Chambers 2001, 195)

\section{Bevezetés}

A tanulmány az „Európa-eszme" jelentését és jelentőségét mutatja be egy multikulturális és multietnikumú földrészen, amely egyre többet merít a nem európai gyökerủek jelenlétéböl és szokásaiból. Az Európa-eszme, még modern alkalmazásában is, a kereszténységen, felvilágosodáson és a romantika örökségén nyugvó ideál marad, amelyet az európai integráció támogatói mozgósítanak mint olyat, ami hídként köthet össze eltérő európai nemzeti kultúrákat. Európában, ahol rendkívüli kulturális kicserélödés megy végbe, és ahova a világ minden tájáról özönlenek a bevándorlók, a klasszikus Európa-eszme meghökkentően kirekesztő és múltba néző - gyenge motívum a jövőhöz.

Ez az eszme nem gyakorol nagy vonzerót a fejlődö országokból bevándorlók egyre népesebb közösségére, akik - jogosan - meg akarják ôrizni diaszpórájuk kultúráját. Kevés kapaszkodót jelent az egyre számosabb kulturális ,hibrideknek”, akik utazásaik, fogyasztásuk, vegyes összetételük és társadalmi mobilitásuk révén komplex 
területi identitást hordoznak: helyit, nemzetit, európait és globálist. A jelek szerint nem inspirálja azt a több millió európai születésü európait sem, akik - félve a „,külső felhigulástól", bármit is jelentsen ez a szókapcsolat - igyekszenek megőrizni etnikai-nemzeti identitásukat és kulturális örökségüket. Európában meglehetösen sokak számára helyi és kozmopolita otthoneszményként egyaránt problémás.

Számít ez a hiányosság? Talán nem, ha az európai integráció ügye az EU-politika múködésének következö vonatkozásaiban keresendö: közös valuta, az egységes európai piac teljessé tétele, a tagállamok közötti kulturális csere, a közép-keleteurópai országok csatlakozásának feltételei, az EU-szintủ intézmények és szabályozások hatálya, és egyéb, határon átnyúló folyamatok, például a multinacionális vállalatok árukereskedése, napi találkozás Európa többi részével a fogyasztás révén és utazások során. Európának nevezett egységes tér épül függetlenül attól, van-e közös identitás és egyesítő eszmény. Ez a magyarázat azonban csak részleges. Az EU vezetői és más Európa-pártiak nagyon is érzékelik, hogy az Európának nevezett hely iránti közérzület és a vele való széles körü azonosulás nélkül a terv akadozni fog, vagy befejezetlen marad; hogy az európaiaknak sok közös régi értéke és hagyománya van (ami részben megmagyarázza a kelet-közép-európai országok iránti lelkesedést és a Törökországgal szembeni fenntartásokat a bővítés vonatkozásában); és hogy Európa örök értékei - a méltányosság, szolidaritás és egyenlőség - különleges globális kulturális és etikai elvként különülnek el a mindenre rátelepedő amerikai mintájú liberalizmussal és a világ más részein jelenlévő barbársággal, babonával és korrupcióval szemben. A jelek szerint tehát az Európa-eszme, bármi legyen is a meghatározása, igenis számít az Európa-projekt jövője és Európának a világ ,„civilizációjában" játszott szimbolikus szerepe szempontjából.

A tanulmány első fele a multietnikumú és multikulturális Európa összefüggésében értékeli a kortárs Európa-eszmét. A második az alternatív Európa-eszme kialakítására tesz kísérletet, amelynek alapja a közszféra speciális politikája és a migrációs térnek tekintett Európához való tartozás különleges étosza, nem pedig az európainak nevezett embercsoport tovább élö kulturális értékei. Bemutat egy megfelelő EU-szintú jogokkal védett közösséget, amely egyszerre támogatja és köti össze a kulturális pluralizmust és a különbözőséget. Európa politikai magprojektjeként demokratikus vitalitást ajánl, az európaivá válás eszméjét, amelynek olvasata az egyenrangú és jogokkal felruházott, többrétegú nyilvánosság lüktető összecsapásaiból származó, soha meg nem nyugvó kulturális alkotás folyamata. Nincs sem eredet-, sem célmítosz, csak a polemizáló kỏznép iránti elkötelezettség.

\section{Az Európa-eszme}

Az Európa-eszme története hosszú és változatos, irodalma nagy (lásd pl. Delanty 1995; Heffernan 1998). Alapja a középkorra visszanyúló régi hagyomány; a kereszténységen, méltányosságon és demokrácián alapuló közös európai identitást ajánl. Megidézték már a béke nevében egy gyakorta erőszakos kontinensen, egységként a közös ellenség (a Török Birodalom, az iszlám, a kommunizmus és az amerikanizá- 
lódás) ellen, és a „másiktól” - eltérő erkölcsi felfogású és kulturális hagyományú társadalmaktól - való különbözőségként. Az 1950-es években az európai egység megalkotóinak az integráció jelentette a lehetỏséget, amellyel - a méltányosságon, a római jogba foglalt igazságosságon, a liberális demokrácián és a keresztényi könyörületességben gyökerezö humanizmuson nyugvó közösség segítségével - a holokauszt borzal mainak megismétlódése egyértelmúen elkerülhetö.

Az Európa-eszme egyszerủbb változata továbbra is áthatja az Európa-projektet, de immár leginkább Európának a világpolitikában elfoglalt helyzetével összefüggő gazdasági és politikai-kulturális okok miatt. A gazdasági vetület egyszerú: a gazdasági integráció gazdaságos termelést és piaci lehetőségeket ígér az Európa Rt.-nek, hogy a világ fóbb piacain versenybe szálljon az amerikai és japán vállalatóriásokkal. A politikai-kulturális vetület továbbra is Európának a világban betöltött „,civilizációs" szerepével áll összefüggésben, amint ezt Jacques Delors-nak a bruges-i College of Europe-beli előadása példázza:
„Azon kapom magam, hogy olyan Európáról álmodozom, amelyik úgy gondozza mérhetetlen kulturális örökségét, hogy annak meglegyen a gyümölcse; Európáról, amely otthagyja a szolidaritás lenyomatát azon a világon, amely túl könyörtelen, és túlságosan könnyen megfeledkezik fejletlenebb tájékairól... Európa örök értékeiröl.," (idézi: Nilsen-Stubb 1998, 68)

Az európai kulturális politika értelmében, amely elismeri, és tiszteletben tartja az egyes nemzetek különleges kulturális örökségét és pályáját, és támogatja ,a demokrácián, igazságosságon és szabadságon nyugvó, közös, pluralisztikus humanizmust", ezek az örök értékek egyszersmind össze is kapcsolják a tagállamokat (CEC 1987, 5).

Az Európa-eszmét az a kritika érte, hogy primitív eszköz az EU állampolgárai közötti „európaiság-érzés” kialakulásának elősegítéséhez. Például az EU Eurobarométer elnevezésủ közvélemény-kutatásai azt mutatják, hogy 1998-ban az EUállampolgárok 43 százalékának nem volt semmiféle európai identitása - ami az 1992 tavaszán mért 38 százalékhoz képest rosszabbodást jelent -, s csak 11 százalékuk gondolta, hogy az európai identitás erösebb a nemzetinél (CEC 1998b; 1998c). Amint Mark Leonard (1998a, 46) megjegyezte, „még az az 50 százalék sem tud határozott jelentést adni a szónak, aki 'európainak' érzi magát; ez olyasmi, amit esetleg akkor éreznek, amikor, mondjuk, japánokkal vagy amerikaiakkal találkoznak". Leonard (1998b, 7) azonban úgy érvel, hogy bár nincsenek erőteljesen átérzett, egész Európán átívelő mítoszok, s ahhoz hasonló történetek sem, amelyek a nemzeti identitásokat kialakítják, van Európának egyfajta „rejtett legitimációja”, amelyet „vakációkról készült pillanatfelvételek öriznek”, és amely egy „eszközrendszer, ami lehetővé teszi, hogy az emberek közvetlenebbül éljék át Európát". Hasonlóképpen vélekedik Chris Shore, aki felvetette, hogy „Európa kulturális sokszínủségének élménye megszámlálhatatlanul sokféleképpen - a szupermarketektől és moziktól kezdve a divatig és az ételekig - lett a mindennapi élet fontos dimenziója" (Shore 1998, 50). Olyannyira, hogy:

„Eric Cantona, Jurgen Klinsmann és Luciano Pavarotti közismert nevek Angliában. A Benetton és a Bata üzletei majdnem minden angol város fỏutcáján megtalálhatók, 
míg a Marks and Spencer Strasbourg-ban és Brüsszelben nyit üzleteket. A Tesco-ban kapható balzsamecet, napon szárított paradicsom, calamata olívabogyó, porcini gomba és frissen sült francia baguette." (Shore 1998, 50)

Azonban, ellentétben Leonarddal, aki a napi kulturális cserén nyugvó Európaeszme lehetőségében hisz, Shore kétségesnek tartja, hogy a fogyasztás új mintái egyet jelentenek a közös európai tudatossággal: „Hogy az angolok jobban kedvelik az indiai konyhát és a német autókat, nem vezet feltartóztathatatlanul indiai vagy németidentitáshoz”, és ,meglehet, az angol szurkolók istenítik Eric Cantonát, attól még utálhatják a franciákat". (Shore 1998, 50)

Az Európa-eszme oszcillál a katolikus értékeken nyugvó eredeti eszmény (amelynek nemrégiben Romano Prodi [1999] adott hangot könyvében, abban a római katolikus alapértékeken nyugvó Európa, ,a lélek Európája” mellett érvelve), Beethoven és a magasztos felvilágosodás, a globális szolidaritás, a balzsamecet és egymás élményének eszménye között. Egyértelmü azonban, hogy a magasztos és a banális elképzelés is a részleges és viszonylag mozdulatlan, területileg definiált európai kulturális identitásokból általánosít. A helyi, nemzeti és európai identitások kulturális sztereotípiák körül stilizálódnak, legyen szó keresztény örökségről, Beethovenről, napon szárított paradicsomról vagy balzsamecetröl. Mit jelentenek ezek az értelmezések egy multikulturális Európában?

\section{Kultúrák egy multietnikumú Európában}

Sok tagállam lakosságának jelentös része nem európai környezetből származik. Az EU nem közöl adatokat sem a tagállamok állampolgárainak etnikai összetételéröl, sem földrajzi eredetéröl, csak az állampolgársággal nem rendelkezókéről (vagyis az adott tagország állampolgársággal nem rendelkező lakosaiéról). Így szignifikánsan alábecsülik a bevándorló népesség számát azzal, hogy nem számolnak azokkal a ,nem bennszülöttekkel”, akik az adott ország állampolgárai (például brit indiaiak vagy holland suriname-iak). Németországban például a lakosság 8,5 százalékát a nem állampolgárok teszik ki, akiknek 74 százaléka nem európai uniós államból származik (CEC 1997a).

Kissé jobb mérce a külföldi születésü lakosság aránya: ez a szám tartalmazza azokat a bevándorlókat, akik állampolgárságot szereztek a befogadó államban, ám nem tartalmazza a befogadó államban született utódaikat. 1994-ben (CEC 1998a) a külföldi születésú népesség aránya a kiválasztott tagállamokban a következő volt: 9,7 százalék Belgiumban, akiknek 41 százaléka EU-országon kívülröl származott; 5,3 százalék Dániában (közülük 74 százalék az EU-n kívülről); 11 százalék Franciaországban (közülük 78 százalék az EU-n kívülről); 9 százalék Hollandiában (közülük 88 százalék az EU-n kívülról); 6,8 százalék az Egyesült Királyságban (közülük 71 százalék az EU-n kívülről); 4,6 százalék Portugáliában (közülük 77 százalék az EU-n kívülröl); és 9,9 százalék Svédországban (közülük 60 százalék az EU-n kívülről). A bevándorló szülőktől származó második és harmadik generációs állampolgárok beszámítása szignifikánsan inflálná ezeket az adatokat (az 1991-es népszámlálás 
adatai szerint például csak a nem-fehér lakosság Nagy-Britanniában 5,5 százalék volt). A tagállamok multietnikumú és multikultúrájú társadalmak lettek. Ez már nemcsak a volt gyarmattartó országokra, Nagy-Britanniára, Franciaországra, Belgiumra és Hollandiára jellemző, vagy olyan országokra, például Németországra is, amelyek olcsó vendégmunkásokat foglalkoztattak, hogy felpörgessék a gazdasági terjeszkedést, hanem többek között Svédországra, Ausztriára, Olaszországra, Görögországra és Spanyolországra is, ahol az új bevándorlási hullám oka a világméretủ szegénység és elnyomás.

Az EU-országok lakosságának viszonyulása a nem EU-országokból érkezö bevándorlókhoz továbbra is ambivalens. 1997-ben, az „Európa a fajgyűlölet ellen évé"'-ben a Bizottság Eurobarométer-felmérése (CEC 1997b) azt mutatta, hogy az EU állampolgárainak 21 százaléka úgy vélte, hogy a „Földközi-tengertől délre eső" területekröl érkezőket, akik az EU-ban akarnak munkát vállalni, nem tanácsos befogadni; 60 százalék mondta, hogy fogadják be őket, de csak korlátozásokkal. Csak 13 százalék vélte úgy, hogy korlátozások nélkül be kell fogadni őket. A spanyolok, finnek, írek, olaszok és portugálok voltak a legbefogadóbbak. Ezzel szemben Belgium (38\%), Görögország, Franciaország (29-29\%), Ausztria (28\%), Németország és Dánia (26-26\%) állampolgárainak több mint negyede gondolta, hogy ezeket a munkásokat nem kell befogadni. A külföldiekkel szembeni érzületek ugyanennyire nyugtalanítóak. Ugyanebből a felmérésből az is kiderül, hogy az EU népességének 45 százaléka véli úgy, túl sok a külföldi a hazájában, 40 százalék, hogy sokan (bár nem túl sokan) vannak, s csak 10 százalék szerint nincsenek sokan. A vendégmunkásokra vonatkozó mintákhoz hasonlóan, az emberek külföldiekkel szembeni attitủdje is nagy eltéréseket mutat a tagállamok között: magasabb a tolerancia Finnországban, Írországban, Spanyolországban és Portugáliában, ám erös az idegenellenesség Görögországban (71\%), Belgiumban (60\%), Olaszországban (53\%) és Németországban (52\%).

A központi kérdést illetően azonban - mármint, hogy fenyegetönek érzékelik-e a multietnicitást/multinacionalitást - az eredmények nem igazolják a megérzéseket. Az 1997-es EU-felmérés azt mutatta, hogy a legtöbb európai nem találja nyugtalanítónak a más nemzetiségüek (83\%) vagy a más faji hovatartozásúak (81\%) jelenlétét a hazájában. A jelek szerint ez a jellemző minta egész Európában Dánia, Belgium és Görögország kivételével, ahol több mint 25 százalék találja nyugtalanítónak a más nemzetiségủek vagy faji hovatartozásúak jelenlétét. Ez az átfogó és országspecifikus véleményminta változatlan volt 2000 tavaszán (CEC 2000a). Az összkép tehát úgy fest, hogy míg a bevándorlás szabályożását az európaiak minden jel szerint kívánatosnak tartják, a többség, föleg, akik a legkevésbé ágyazódtak be kizárólag a nemzeti tradíciókba, viszonylag bizakodóak - 2001. szeptember 11-e elöttig legalábbis azok voltak - az országukban már letelepedett más nemzetiségüek és etnikai csoportok jelenlétével kapcsolatban. Mindezt alátámasztja a 2000 augusztusában végzett Eurobarométer-közvéleménykutatás alapján elkészített 1. táblázat, amely az EU-polgárok európai integrációval összefüggö félelmeit tartalmazza. Nincsenek közvetlenül idegengyülölő vagy fajgyülölő félelmek, bár a 
gyakoribbá váló drogcsempészettel, a szervezett bủnọzéssel és a nemzeti önazonosság elvesztésével összefüggő aggodalmak a válaszadók gondolkodásában kapcsolatba hozhatók az erőteljesebbé váló bevándorlással.

\section{TÁBLÁZAT}

Az EU-állampolgárok legfontosabb félelmei

(Most Important Fears of EU Citizens)

\begin{tabular}{lc}
\hline \multicolumn{1}{c}{ Félelmek } & $\begin{array}{c}\text { Az Eu-polgárok } \\
\% \text {-ában }\end{array}$ \\
\hline A munkahelyek áthelyezése az alacsony költségú országokba & 60 \\
A gazdák nehézségei & 60 \\
A nemzeti valuta megszünése & 58 \\
A kábítószer-kereskedelem és a szervezett bủnözés növekedése & 56 \\
A potenciális tagok túl sokba kerülnek az EU-nak & 53 \\
A szociális juttatások elvesztése & 51 \\
Kisebb EU-támogatás & 48 \\
A nemzeti identitás elvesztése & 47 \\
A gazdagabb országok többet fizetnek a többieknek & 45 \\
A nyelv elvesztése & 42 \\
A kis államok hatalmának elvesztése & 38 \\
\hline
\end{tabular}

Forrás: CEC 2000b.

\section{Kozmopoliták és hibridek?}

Hogyan függenek össze az idegenekkel szembeni vegyes attitúdök a változó Európa-eszmével? Mennyire fejezik ki a tolerancia gyenge jelei a „,mi” és az „ök” között húzódó határok elhomályosítását a többszörös kötődések kialakulóban lévő poszt-nacionalista kultúrájában? Vagy a tolerancia nem több a „,másik” legitimációjának felismerésénél mindkét oldalon? Valóban beszélhetünk toleranciáról Európában, amelyet a reakció és fajgyúlölet új formái, nevezetesen a 2001. szeptember 11. után felerősödött beteges irtózás az iszlámtól és a menedékjogot kérők bünözőkként és jóléti opportunistákként történő megbélyegzése jegyez? Túl egyszerủ megoldás talán egyetlen állásponttal beérni, hiszen annyira hihetetlenül sokszínüek az Európával és a bevándorlókkal szembeni nemzeti érzületek, az európai bevándorlás- és fajgyülölet elleni politikák, kulturális preferenciák és identitások. Azt azonban igenis állítom, hogy amennyiben új Európa-eszme van kialakulóban, az nem a kulturális keveredés és a hibriditás eszméje, hanem a különbözőség követelésén nyugvó eszme, és olyan módokon, amelyek nem felelnek meg a hagyományos Európaeszmének.

A bevándorlók Európájának haladó szellemü értelmezése az, miszerint a bevándorlás nyomán kialakuló hibriditás összhangban van a hagyományos kulturális határokat lebontó kozmopolitizmus szélesebb folyamataival. Így, a többszörös identitás és a többszörös területi hovatartozás dicséreteként, Európa „kevés poggyásszal 
utazhatna" (Pieterse 1999; 2001): ez egy folytonos kulturális áramlásban lévő hibrid Európa. Ez az az Európa, amelyet a posztmođern kulturális elemzők, akik a helyi identitásoknak a globális kulturális keveredés körülményei közötti hagyománytalanításáról írnak, a magukénak vallanak. Európában is mindannyian többszörös identitású és hovatartozású hibridek lettünk:

„A társadalmi pozíciók, a kapcsolódó hálózatok és referenciacsoportok elszaporodásával kialakult hovatartozások többszörös kötelékébe bonyolódott egyênek ... Sokkal gyakrabban lépünk be ebbe a rendszerbe, és lépünk ki belőle, mint régen. Vándorló állatfaj vagyunk. ... Ránk nehezedik tehát a nyomás, hogy változzunk, áthelyeződjünk, hogy megfeleltessük azt, amik egy perccel ezelött voltunk a kapcsolatok új kódjainak és formáinak." (Melucci 1997, 61)

Zygmunt Bauman (1997) is azt mondja, hogy a hagyománytalanítás, a szabályozás feloldása, az új világrendetlenség és meghatározatlanság nyomában kialakuló „bizonytalanság mindent elárasztó érzése” és a „körülvevő félelem” $(1997,50)$ új „,heterofil korszak” kellös közepébe helyez bennünket, amelyben „már nem az a kérdés, hogyan szabaduljunk meg az idegenektől vagy az idegenszerütöl, hanem az, hogyan éljünk együtt velük - nap mint nap és állandóan" (1997, 88). Normatív szempontból ez az értelmezés megnyitja az utat a többszörös és mozgásban levő identitások Európája, és a ,köztünk” és „,köztük” levő különbségek fokozatos eltünése felé. Olyan - egyszerre kisebbségi és a fö áramlathoz tartozó - Európa ez, amelyik visszafordíthatatlanul halad kozmopolita önmaga felé, miközben a kulturális keveredés kétségbe vonja az alapvető fontosságúnak kikiáltott hovatartozásokat.

Ettől a kozmopolitizmustól Európa nagyon más eszményt kaphatna, ami nemzeteken átívelő dacos önazonosításokra összpontosítana. Európa a kozmopolitizmust tehetné meg az integráció és a befogadás új eszményévé, amellyel elkerülhetné az uralkodó Európa-eszmével társuló elitizmust és Európa-centrikusságot, és megmutathatná, hogy a kozmopolita törvényeken és egyetemes jogokon nyugvó, eredeti kantiánus békeformula új eröre kaphat, hogy normalizálhassa és megvédhesse az elvet, hogy európainak lenni annyit tesz, hogy dicsérjük a vándorló identitásokat (Joseph 1999) és kulturális keveredést.

Ez új és vonzó Európa-eszme, amely a társadalom különféle szeleteiben - a kisebbségben és a többségben, a hazai születésüek és a bevándorlók között - megtalálható, az államok iránti, közös „érzelem nélküli hüségre” és a „,szolidaritás gyenge mintáira" (Turner 2000, 28) játszik rá. Azonban azt is feltételezi, hogy a kozmopolitizmus széles körben elterjedt kulturális megkülönböztető jegy. Milyen bizonyítékok támasztják alá, hogy Európa „kevés poggyásszal utazik”? A kép nem letisztult. Elöször is, ha visszatérünk Meluccihoz, a „„öbbszörös én” állapota és tudata két, egymástól nagyon különbözö, s valószínúleg egymásnak ellentmondó állapot:

„... létezik egy mélyreható erkölcsi következmény: a megtartás és az elvesztés szükségessége, a félelmekkel és ellenkezésekkel vívott harc, de az is, hogy túl tudjunk lépni saját identitásunkon. [...] Ahhoz, hogy találkozhassunk egymással, jókora ugrásra van szükség a tudatosságban, amely lehetövé teszi, hogy elfogadjuk: független individuumok és társadalmi csoportok vagyunk, ugyanakkor egymás mellett létezünk és kommunikálunk." (Meluccihoz 1996, 116) 
E ,jókora ugrás" nélkül - amely, mindaddig, amíg folytatódik az Európa-projekt, valószínüleg nem szül sem közönyt, sem ellenségeskedést, - a „félelmek és ellenkezések" nagyon is uralhatják a határok érzékelt eltủnésére és a fenyegetett nemzeti identitásra adott reakciókat. Nem egyfajta értelmezése ez a fajgyälı̈let, a vallási fundamentalizmus és a nacionalista érzületek napjaink Európájában tapasztalt újraéledésének? Abban az Európában, ahol már nincsenek meg a hovatartozás régi bizonyosságai; ami elmélyíti a változással szembeni védekező magatartást, és súlyosbítja a különbözőséggel szembeni türelmetlenséget. Az etnikai tisztogatás, a bevándorlók és menedékjogot kérök elleni erőszak, a nacionalista zászlólobogtatás, a regionális szeparatizmus, a kisebbségek követeléseinek és a többség visszacsapásainak Európa-szerte fellángoló harci villongásai bőséges bizonyítékkal támasztják alá ennek lehetöségét.

Akkor felmerül a kérdés, kire vonatkozik a hibrid vagy kozmopolita címke. Jonathan Friedman $(1997,79)$ bizonyossággal állítja, hogy csupán egy szük kulturális elitre - a „gyarmatosítás időszaka után felbukkanó határátlépőkre”: költőkre, müvészekre és értelmiségiekre. Robin Cohen is célzott éllel jegyzi meg:

„Vannak azok, akik üdvözlik az új bizonytalanság eszméit, akik saját narcisztikus céljaik érdekében kutatják a fragmentálódás és képlékenység burjánzó fenomenológiáját, és a kulturális vagy politikai előrenyomulás helyszíneként fetisizálják a határokat. Ezenközben a bevándorlók és a menedékjogot kérök, a munkanélkủliek és az elesettek, vagyis mindazok, akiknek biztonságra és védelemre van szükségük, gyakran lényegülnek át egyfajta nomád posztmodern hösökké azok szemében, akik a biztonságot és a védelmet magától értetődőnek veszik." (Cohen 1998, 15)

A közelmúltban Jan Nederveen Pieterse (2001) reagált erre a fajta kritikára, újra megerősítve, hogy az emberi és nem emberi élet története a rétegzett hibridizáció története; ahol nem maga a hibriditás, hanem a rögzült és tiszta kategóriák lényegivé tétele az analitikai probléma. Véleménye szerint a hibriditáseszmék rávilágítanak a „határok fetisizálása társadalmi tendenciájának” (Pieterse 2001, 1) azon problémáira, amelyek továbbéltetik a „mi”, kontra „ok” típusú gondolkodást, mialatt továbbra is a társadalmi és geográfiai spektrum egészébe beágyazódott keveredés valósága marad a realitás. Nagyon is elképzelhetö, hogy a hibriditás gyakoribb jelenség, mint azt a kritikát megfogalmazók feltételezik, ám helyesen mutatnak rá, hogy a dicsőító irodalom elsiklik a kis elörenyomulásban érintett nagy társadalmak anyagi és kulturális politikái fölött. Egy ilyen politika magukat a társadalom alján találókat - a bevándorlóktól és hontalanoktól az elidegenedett fiatalokig és munkanélküliekig -, saját anyagi és társadalmi jólétük érdekében, gyakran kényszeríti (választással és elöítélettel) zárványszerü csoportokba és szokások gyakorlására.

De a „törzsiség időszaka” (Maffesoli 1996) általánosabb megpróbáltatás; a társadalom „fö áramlatainak” szintjén, az ,átlagos” háztartásokban, szomszédságokban, munkahelyeken és a nyilvános terekben a közösség és a hagyományok hipermodernizáció és globalizáció okozta csendes elsodródása megerősíti a mások elleni, kézzel fogható határok iránti erös vágyat. Lehet, hogy mindannyian hibridek vagyunk, ahogy Pieterse (2001) állítja, ám - a jelek szerint - csak kevesen fogadjuk 
el, mivel ez megkérdỏjelezi a kívülállókkal szembeni saját vegytisztaságunkat és felsőbbrendüségünket. Bizonyos európai kulturális konfliktusok a következő fogalmakban érzékelhetők: az integráció, az amerikanizálódott fogyasztás, a brüsszeli „,bürokrácia”, a bevándorlók és menedékjogot keresők, az etnikai és egyéb regionalista mozgalmak előretörése okozta kulturális veszteség miatti aggodalmak. Ezek nagyon is valós, a különbségeket jelzỏ éles földrajzi és kulturális határokhoz kapcsolódó aggodalmak. Köszönöviszonyban sincsenek a hibriditással!

Hasonló a helyzet a szántszándékkal hibridekké válók között: hiányzik a kozmopolitizmus biztonsága. Érzékeny múvében, amely hat, vegyes házasságból született nöröl szól, és Angliában játszódik, Jayne Ifekwunigwe (1999) az olvasó elé tárja, hogyan válik az elkerülhetetlen fajkeveredésben zajló mindennapjaik részévé az öngyülölet, zavarodottság, a fehér vagy fekete bőrü lét érzete közötti ingadozás és, mindenek felett, a fehér és fekete közösségtöl egyaránt érkező gúny, elszigetelődés és a kategorizálás. Így Ruby, aki fehér bőrủ férjével és egy fehér bőrủ barátnőjével utazgat Marokkóban, amikor automatikusan cselédnek nézik, arról panaszkodik, miként éreztették vele, „hogy a férjem és fehér börü barátnőm házasok, és hogy a gyerekek az övék. Fájdalmas és elszomoritó volt." (Ifekwunigwe 1999, 80) Akoussa - élettapasztalata alapján - hasonló következtetésre jut: „Úgy hiszem, hogy - mindent összevetve - a Fehér társadalom sohasem fogadott be. Úgy néznek rám, mint aki beszennyezi a fajtájukat, mint egy betegre; ami még két fekete szülönél, még annál is rosszabb. Ha népirtásra kerülne sor, valószínüleg velünk kezdenék." (Ifekwunigwe 1999, 112) Ebből a két élményből nyilvánvalóan nem lehet általánosítani, mivel a társadalmi közeg, az osztály-hovatartozás és a bőrszín valószínüleg számítanak, ám amit valóban felmutatnak, az a hibriditás meggondolatlan dicsőítésének veszélyei.

\section{Hagyomány és különbözöség}

A különbözőség mindenekelött a kisebbségi etnikai-kulturális csoportoknak fontos. Vegyưk példaként az EU-ban élő 17 millió muzulmánt. Az első generációs muzulmánok józansága, jámborsága és alkalmazkodása (Werbner 1996) nem teremtett olyasmit, mint amit Angliában, Francia- és Németországban és más európai országokban a későbbi generációkban fellelhetö sötét börü európaiak vagy világpolgárok (kivéve talán a hozzám hasonló mobilis, félig már elszakadt, liberális értelmiségiek körét). Ehelyett, Yasmin Alibhai-Brown szavaival élve:

„Érdekes módon a fiatal, nagymúveltségú muzulmánokban a felsőbbrendúség új érzése alakul $\mathrm{ki}$ az áldozatlét révén. Sokukat vonzza az intifáda és a megvalósíthatatlan, bár romantikus, pán-iszlám identitás eszméje, és az az elképzelés, hogy élhetnek a saját képzeletbeli ideológiai és vallási területeiken." (Alibhai-Brown 1998, 39)

Alibhai-Brown (2000) a brit muzulmánokra vonatkozóan azt állítja, hogy a spektrum - a jelek szerint - polarizálódott azokra, akiknek az iszlám identitás a legfontosabb („számukra az integráció jöhet a legkevésbé számításba”), és a fiatal muzul- 
mánokra, akik ,önmagukra a társadalomban helyüket kereső, szavazati joguktól megfosztott más csoportok szélesebb mozgalmának részeként gondolnak" (AlibhaiBrown 1998, 39; az ilyen szövetségek révén Malmőben megteremtett muzulmán másság megkapó történetét lásd Ristilamminál 1996). Európa egyik esetben sem játszik pozitív szerepet: ,a feketék és az ázsiaiak között széles körben elterjedt nézettől eltekintve, miszerint Európa fehér véderöd a fejlödö világ ellen, vagy hogy mi itt Angliában jobban élünk, mint az 'etnikai kisebbségek' a partnerországokban, nincs kapcsolódási pont az EU-projekthez" (Alibhai-Brown 2000, 8-9).

Létezik a diaszpórakötelékeket és a társadalomtól kért letelepedés/állampolgárság eröteljes igényét magában foglaló hovatartozás alternatív geográfiája. Szüleikhez és nagyszüleikhez hasonlóan, a fiatal muzulmánok a társadalmi többségtöl eltérỏnek tekintik magukat, ám velük ellentétben, sajátjukként formálnak igényt a nemzetre. Már nem Angliában, Franciaországban és Németországban élö muzulmánok, hanem angol, francia és német muzulmánok, s ebböl adódóan a nemzeti közösség részesei, mint bárki más. Az Észak-Anglia városaiban nemrégiben lezajlott etnikai zavargások árulkodó aspektusa, ugyanakkor a francia, német, belga, holland és skandináv városokban tapasztalható kortárs etnikai kisebbségi tiltakozások közös vonása is, hogy nem csak a kisebbségi igények elismertetéséröl szóltak. Azzal, hogy a szomszédságokra, utcákra, parkokra és mủemlékekre sajátjukként tartottak igényt, a fiatal tüntetők alapvetỏen kérdőjelezték meg a feltételezéseket, hogy kiéi is a nyilvános terek, amelyeket addig a fehér többségéinek és a nemzeti örökségbe ágyazott konvenciók körül kialakultnak tekintettek. A helyi fehér lakosságot, a médiát és a nemzeti lelkületet - úgy tünik - a leginkább az háborította fel, hogy a „bevándorlók”, bár jogosan követeltek állampolgárságot, és formáltak igényt a helyi születésre, vették maguknak a bátorságot, hogy megváltoztassák a helyi és nemzeti hovatartozás szimbólumait, mintha arra kérték volna a királynőt, hogy viseljen csadort. Mindebben - bár fontos következményekkel jár a nemzeti kisebbségekre és a többségre nézve, kezdve a gazdasági és pénzügyi uniónak a munkahelyekre, megélhetésre és a szabad mozgással összekapcsolódó kényszerü helyváltoztatásra kifejtett hatásától egészen addig, hogy a fontos politikai döntések centralizáltan Brüsszelben vagy Strasbourg-ban születnek - Európa mint a hovatartozás tere - furcsa módon - nem vesz részt.

Az etnikai változtatást, természetesen nem mindenki viseli megkülönböztető jelként, mivel, ahogyan Jeff Spinner-Halev $(1999,69)$ megjegyzi:

„Amikor a mélyen vallásos szikhböl kanadai lovas rendör lesz, otthon hamburgert eszik, és hétvégén kimegy a Toronto Blue Jay baseballmeccsre, a gyerekei a University of Torontora járnak, ahol részesei a saját kozmopolita életüknek, akkor ő és a családja azt a kozmopolita életet éli, amelyik több kulturális hagyományból táplálkozik."

De ne ragadjon el bennünket ennyire a hév! A kozmopolita élet kíséröjeként gyakran megjelenik az etnikai identitás, amely a közösség mindennapi biztonságának és kulturális táplálékának forrása. Pontosan ezzel magyarázható, hogy - a nemzeti és európai kulturális asszimiláció irányában tett minden egyes lépéssel - nỏ az 
igény a felekezeti iskolák, a kulturális és vallási autonómia, a „szülőföld” felkeresése, az „otthonról” szóló történetek vagy a család- és diaszpóratörténetek rekonstruálása iránt (Werbner 1996). Ez azonban nem az elszigetelödési politika követéséből fakadó elutasítása az uralkodó irányzatnak, hanem egy etno-kulturális vetület átérzett értékének a jóváhagyása a másokkal való közös összekapcsolódás kötelékében. Amint Bhikhu Parekh (2000) kifejti, ,,az ember ... kulturálisan strukturált világban él, és ... nagy értéket tulajdonít kulturális identitásának”, olyannyira, hogy ,a különböző kultúrák a jó élet jelentésének és vízióinak eltérő rendszereit képviselik" (Parekh 2000, 336).

Parekh $(2000,337)$ azonban azt is megjegyzi, hogy mivel ,a legprimitívebb kultúrák kivételével minden kultúrának belsö pluralitása van, és ezek folyamatos párbeszédet jelenítenek meg eltérő hagyományaik és gondolkodásmódjuk között"; mindegyik hordoz magában valamennyit a másikból; ritkán - sui generis - „porózus szerkezetủ és a külső hatásoknak kitett”. A központi kérdés tehát az, hogy mindezt felismerik-e és elfogadják-e. Aggasztó az a vonulat, melyben a kulturális különbségekről szóló párbeszéd a fundamentalisták malmára hajtja a vizet; a fundamentalistákéra, akik a bevándorlóktól és az „idegen” kulturális hatásoktól megtisztított, vér és rög szerinti területi hovatartozás Európáját követelik. A faj- és idegengyülölet gyorsan válik összeurópai jelenséggé: már nem csak egy-egy országban tapasztalható, $s$ nem lehet kényelmesen elhessenteni, mintha valamiféle kivétel volna az egyenlö jogok, a szabadság és a szolidaritás érintetlen európai hagyományai alól. A nem fehér bőrü bevándorlókkal szemben húsz-harminc éve Angliában, Franciaországban és Németországban megnyilvánuló kendözetlen fajgyülölet „az emberi fajták állítólagosan eltérỏ képességeire" játszott rá (Stolcke 1995); ez volt a bevándorló (török, indiai, pakisztáni, afro-karibi és észak-afrikai) etnikai kisebbségekkel szemben megnyilvánult diszkrimináció és erőszak alapja a lakás- és a munkaerőpiacon és a különbözö politikai és szociális jogok megszerzése területén, az utcán és a médiában. Bizonyos elemek még ma is megtalálhatók - talán nem annyira kendőzetlenül, mint a múltban, és csak a tudatosan fajgyủlölő egyénekben és szervezetekben -, és átterjedtek más országokra is, amelyek az utóbbi időkben váltak a bevándorlók célpontjaivá. A faj- és idegengyülölet megnyilvánulásának sok rémsége megismétlődött abban, ahogyan az olaszok reagáltak a különböző afrikai országok felől érkező bevándorlási hullámra a nyolcvanas években (Melotti 1997), továbbá a svédeknek és a dánoknak a világ minden tájáról érkezö üldözöttekkel szembeni liberális menedékjog-politikával szembeni reakciójában. Ragyogóan fogja meg a helyzet lényegét Allan Pred (2000) könyvének címe: „Még Svédországban is", a haladó szellemủ szociáldemokrácia és a liberális értékek hazájában a fajgyúlölet - különféle permutációiban - nyilvánvalóan jelen van már.

Ám az új fajgyülölet, pontosabban az új „,kulturális fundamentalizmus” (Stolcke 1995), amely a kulturális különbségekre mint az etnikai alapon történö megkülönböztetés igazolására játszik rá, pán-európai jelenséggé nőtte ki magát a bevándorlók régi és új célországaiban egyaránt (Modood 1997). Míg a régi módszer az volt, hogy a bevándorlókat kirekesztették, vagy nemkívánatos, illetve beilleszkedni nem 
tudó idegenként visszatoloncolták, az új jelenség aggodalmakat fogalmaz meg a negatív következményekkel kapcsolatban, mind „ránk”, mind ,rájuk” vonatkoztatva, akik „,közöttünk vannak”. Ök és kulturális szokásaik - az imádságtól és az ideológiától kezdve a fogyasztásig és a szórakozásig - felhígítják és aláássák szent hagyományainkat és etno-nemzeti integritásunkat. Verena Stolcke $(1995,12)$ a következöképpen foglalja ezt össze:

„A jelenkori kulturális fundamentalizmus kétségtelenül közös kulturális örökségben gyökerezteti a nemzeti hovatartozást és az állampolgárságot. ... A feltételezés, hogy a területi alapon szervezödött ország és annak lakossága zárt, megkülönböztethetỏ és körülhatárolt kulturális örökségen nyugszik, [e fundamentalizmus] alkotóeleme."

Még a deklaráltan idegengyủlölök és nacionalisták is, akik egyre inkább kihasználják a fehérek és a feketék mindenféle szövetségét, az átlaghoz hasonlóan, „,kulturális relativisták" lettek. Kampányt folytatnak a nemzeti és regionális kulturális örökség megmentéséért, panaszkodnak az Európából érkezö betolakodásra, aggódnak, mert veszélyesnek érzik a kisebbségek által követelt jogokat (például speciális iskolák, ünnepeik, ünnepségeik, szokásaik elismertetése, társaságaik anyagi támogatása stb.), és javaslatokat tesznek, hogyan lehetne az etnikai közösségeket elkülöníteni (a gettósítástól az önkéntes visszatelepülésen át a szigorúbb idegenrendészeti szabályokig). Az új közhangulat nem annyira a fajkirekesztő, mint inkább a nemzeti kulturális sztereotípiák iránti hủségen nyugvó politikákra játszik rá; s a tagság joga valószínủleg átível az etnikai határokon (például a krikettet kedvelö indiaiak az angoloknak szurkolnak, amikor Anglia India ellen játszik; vagy a palesztinok a mindenhol megtalálható nemzeti zászlót lobogtatják Dániában, vagy lelkesedéstől kikerekedett szemmel sereglenek a májusfák köré Svédországban május elsején). Nos, a hovatartozás próbája inkább a kultúra, mint a bőrszín vagy a külső ismertetöjelek; ám ez ugyanennyire kirekesztỏ, és ugyanennyire türelmetlen a kulturális keveredéssel szemben.

Összefoglalva: egy sor szubjektum-pozícióból nézve, az új Európa átjárható határaival - minden jel szerint - sokkal kevésbé tere a boldog hibriditásnak, kozmopolitizmusnak és a „régi” európai értékeknek, mint a különféle erősségü kirekesztéseknek és a kulturális különbségek nevében beszükített határoknak. És valóban: ironikus módon az új kulturális fundamentalizmus a különbözőségnek nagyrészt ugyanazon politikáira épít, mint a csoportautonómiát támogató multikulturális társadalmak érdekében történő haladó szellemủ érvelések. Kenan Malik (1998) például úgy véli, mind a kulturális különbségek dicséretében gyökerezö fajgyülölet, mind a fajgyủlölet elleni projektek révén az identitások igen gyakran mítoszok köré kövülnek és lényegülnek, ahelyett, hogy a ,közösségek által szabadon választott identitások" alakulnának ki (Malik 1998, 134), aminek az a következménye, hogy „az egyenlötlenségeket megtürik és súlyosbítják" (Malik 1998, 125). Jeff Spinner-Halev $(1999,65)$ továbbmegy:

„A multikulturalizmus, amely több különálló kultúrával próbál meg társadalmat létrehozni, mélyen fenyegeti az állampolgárságot. Ilyen multikulturális társadalomban az embereket nem érdekli az állampolgárság; az sem, hogyan lehet mindenki számára 
kellemesebbé tenni a nemzetet; nem nagyon törödnek vele, hogyan hat a politika a legtöbb emberre vagy honfitársaikra. Még a „honfitárs” szó is idegenül cseng számukra. Vannak zsidó, fekete bőrű, muzulmán vagy szikh társaik. Honfitársaik viszont nincsenek."

Ebben a kulturális összefüggésben a régi Európa-eszméröl fokozatosan kiderül, hogy az egység korlátolt eszköze.

\section{Egy másik Európa-eszme}

Mit jelent európainak lenni olyan térben, melyet az állandó mobilitás és átmenetiség, a világ minden részéről jelen lévő multikulturalizmus jegyez, s ahol az Európának nevezett helyhez lazán kötődnek? Érdemes újra kitalálni Európát mint eszményt? Vagy ésszerübb az európai gazdasági és politikai integráció szolgálatába állított pragmatizmus alá rejteni ezt a tỏrekvést, s helyi és országos döntésekre bízni a szociális és kulturális ügyeket? A (nacionalista, diaszpóra vagy pluralista) különbözöség politikája-e a legjobb, amit remélhetünk, amit a nemzetállam és egyéb értelmes szerveződések és elkötelezettségek szintjén megkérdôjeleznek?

Úgy gondolom, érdemes megörizni valamilyen Európa-eszmét, mert minden integrációs lépés közös gondokat és fejlesztéseket jelent, amelyekhez közös normákra van szükség, és mert Európa nevében a társadalmi igazságosság, összetartozás és kulturális tolerancia új, nemzeteken átívelö eszményeire tarthat igényt. Azonban nem Európa ,európaiságát” kívánom megvédeni - régóta fennálló kőzös kulturális megjelenési formákat, mint a katolikus könyörületesség, a protestáns etika, a 'pasta' vagy Beethoven. Amit meg akarok védeni, az inkább valamiféle étosz, így az idegen empátiával fogadása, a kölcsönhatásban formálódó különbözőség, amelyet az európai politikai filozófia - az egyetemes szabadságjogok felvilágosodás kori eszménye, a francia forradalomnak az egyenlö és szolidáris társadalomról alkotott eszménye - elemeire támaszkodó jogok segítenek. Ezt a szintet megcélozva a vita visszatérést jelent bizonyos elvont politikai-filozófiai elvekhez, azok kiegészítéséhez és kiterjesztéséhez annak érdekében, hogy az európai multikultúráknak ủj irányokat szabjanak. Mint ilyen, nem hordozza a vonakodó kozmopolita, amerikanizált, nemzetcentrikus vagy diaszpóra népességre rátelepedỏ európai kulturális tradíciók ,nehéz poggyászát”. Viszont nagyon is igényli a tudatba nehezen besulykolható és nehezen megvalósítható „közös érdekek és a ragaszkodás kötelékeivel összefogott" politikai közösség iránti elkötelezettséget (Parekh 2000, 341).

Julia Kristeva szerint ,a szabadságról vagy az emberi méltóságról alkotott európai vízió" (2001, 43) nagyban eltér a jogok és szabadságjogok liberális amerikai hagyományától, amelyet a tudomány és gazdasági haladás hasznosságával és számításaival hoz összefüggésbe. Feltételezése szerint az európai „társadalmi élmény” és "gondolkodásmód" alapja lehet:

„,a bensőséges, a különleges, az életmüvészet, az ízlés ( $g o ̂ u t$ ), a pihenés (loisirs), a cél nélkủli öröm (plaisirs pour rien), a kellem/kegyelem, (grâce), a véletlen (le hasard), a játékosság (le ludisme), a pazarlás (gaspillage), az 'elátkozott énünk' (la part 
maudite), vagy rơviden a szabadság mint a minden más 'ïgyet' megelőző 'világon való létezés lényege'." (Kristeva 2001, 42)

Nem győz meg teljesen, ahogyan Kristeva különbséget akar tenni a haszonelvủ Amerika és a költooi magasságokban lebegó Európa közöit; az sem, ahogyan kulturálisan jellemzi az európaiságot (bár abban egyetértek vele, hogy gyorsan fogyasztó és számító korunkban nagy szükség van arra, hogy ezek a kulturális jellemzők a régi önmaguk legyenek).

Inkább a „minden más ügyet megelözó világon való létezés” gondolata az, amely - mint egy multikulturális Európa filozófiai lényege - megragad. Ismét Kristevát idézve:

„Létezik ... egy másik elképzelés a szabadságról, amely a görög világban bukkan fel. Filozófiájának lényege a Szókratész előtii gondolkodás, amely a szókratészi párbeszédben bontakozik ki. Anélkuil, hogy valamilyen ügynek lenne alárendelve, azaz már a tudományos és mủszaki gondolkodás premisszáiként múködỏ arisztotelészi 'kategóriák' összefüggését megelőzỏen, ez az alapvetô szabadság a léten, sôt, az eppen felszabadított nyelv létén (l'être de la parole qui se livre) nyugszik, amely önmagához és a másikhoz szól, és így felszabadítja önmagát" (Kristeva 2001, 40; eredeti kiemelés).

Számomra az új Európa-eszme két alapelve ebből a társadalomontológiából fakad: elvont elvek, amelyeknek inkább az emberi méltóság és kulturális megbecsülés európai színvonalához, mint az európaiak közös kulturális hagyományaihoz van kỏzük. Kifogásként fel lehetne hozni, hogy egy ilyen szinten egységes projekt megvitatása szükségtelen, ám az a keserủ igazság, hogy mindezt szükségessé teszi az Európában mostanában tapasztalható egyre nỏvekvố méltánytalanság, amelyet a politikai menedékjogot kérőknek, a harmadik világból érkezóknek és a muzulmánoknak el kell szenvedniük; azok a méltánytalanságok, amelyek már nem csak jelenlétük jogát, hanem gyakran alapvető emberi jogaikat is megkérdöjelezik.

Az egyik elv a vendégszeretet elve, amelyet Kristeva (2001) etimológiailag a görög étosz szóhoz kapcsol, s amelynek jelentése menedék (hely), vagy a rendszeres ott-tartózkodás szokása. Ez ihletö és fontos étosz egy olyan Európa számára, melyet a globális etnikai és kulturális keveredés, és a nagyfokú emberi mobilitás különböztet meg. Az idegen iránti vendégszeretetet jelentő Európa-eszme szerint európainak lenni annyit tesz: vendégül látni az idegent. Kristeva $(2001,35)$ szerint „felépíthetủnk valamit ebből a szolidaritásból, mivel mindannyian az emberiség eljövendó típusát alkotjuk: a teljességgel az egymást megérteni próbáló külföldiek/idegenek alkotta típust". Jacques Derrida (2001) hasonló felvetéssel lépett fel: Európában az etikát mint a vendégszeretet elvét úgy lehetne haladóvá tenni, ha visszatérnénk a városok mint menedékhelyek középkori eszméjéhez (érdekes, hogy az államot úgy állítja be, mint ami nagyon is belegabalyodik a nem állampolgárok befeketítésének gyakorlatába). A városok a most már „vendégnek” tekintett kívülállónak ismét a biztonságos menedéket jelenthetik a látogatás és a lakhatás jogának segítségével. Továbbléphetünk, és elgondolkodhatunk azon, hogy a menekült alakjának - amely most már tömegesen van jelen Európában, jogai viszont gyakorlatilag nincsenek ki kellene kényszerítenie, hogy a nemzeti állampolgárság révén történó teljes jogát- 
ruházás modern mércéjét radikálisan újragondolják. Arról van-e csak szó, hogy Európa továbbra is korlátozza a nem állampolgárok növekvő seregének jogait?

Az új Európa-eszmében a menedék és nem az állampolgárság elve lehetne az elismerés központi joga, ahogy Giorgio Agamben elképzeléseiben megfogalmazza:

„El tudnánk képzelni olyan Európát - nem valamiféle megvalósíthatatlan 'nemzetek Európáját', amelynek katasztrófája már rövid távon elörelátható, hanem területtől független, területen kívüli teret -, ahol az európai államok minden (állampolgársággal rendelkező és nem rendelkező) lakosa az exodus vagy a menekülés állapotában lenne; az európai státus ez esetben az állampolgár exodus-létét jelentené (olyan állapotét, amely nyilvánvalóan lehetne a mozdulatlanság állapota is). Az európai tér így tovább már nem egyszerüsíthetö különbséget jelentene a származás [nascita] és a nemzet között, amelyben a nép régi fogalma ... ismét politikai jelentést nyerhetne, $\mathrm{s}$ ezért határozottan szembehelyezkedne a nemzet fogalmával ... Ez a tér nem esne egybe sem a homogén nemzeti területekkel, sem azok topografikus összességével; inkább hatással lenne rájuk azáltal, hogy topológiailag artikulálja és perforálja öket, akárcsak a Klein-palackban vagy a Möbius-szalagban, ahol megállapíthatatlanná válik a külső és a belsö. Ebben az áj térben - a kölcsönös területenkívüliség kapcsolatába belépve - az európai városok újra felfedeznék a világ városainak ősi hivatását ..." Agamben (2000, 23-24)

A következő részben visszatérek a „milyen jogokat, kiknek” kérdésére.

Az új Európa-eszme második elve, amelyet Kristevától átveszek, a kölcsönösség nyilvánossága mint a multietnikus Európa kulturális alkotmányának sarokköve. A kortárs kultúra-elmélet és a posztkoloniális írások gyakorta ismételgetik, hogy felépítésünk kölcsönösségben és dialógusokban formálódik, ám ennek hatása az „,önmaga" és a ,másik" tudatára paradox. Mobilis és többszörös identitásaink megtestesülése a másokkal és a különbözó kulturális hatással való különféle interakcióinkban egy globalizálódó világban összeakad az idegen és idegenszerüség mint határcélpont iránti igényünkkel, azzal, ami nem „én” vagyok, ami a nemkívánatos vagy különböző „,másik”. Az idegen bennünk van, nem pedig egy közülünk. Ezt a paradoxont érzékelteti csodálatosan a következỏ részlet, amely a hovatartozás ambivalens kérdését ragadja meg, amelyet a rohanó, modern Párizs szívében élő ösöreg, régi vágású arab írástudó jelenléte vet fel még egy kozmopolita angol gondolataiban is:

„A párizsi Barbés-ban, amely gyalog tíz percre van a Gare du Nord-tól, és amelynek nemrégiben kiterjesztették határait, hogy most már odatartozzék a Gare du Londres is - ahonnan a szupergyors Eurostar indul két óra ötven perces útjára, a La Manchecsatornán át a Waterloo pályaudvarra -, arab írástudókat lehet látni amint ott üldögélnek az utcasarkokon. Kuncsaftjaik, csakúgy, mint azokéi, akik az ötvenes években a kormányhivatalok környékén lófráltak a trinidadi Port of Spainben, amint azt V.S. Naipaul leírásából ismerjük, vagy, ha már itt tartunk, a mai Nápolyban, analfabéták. Pár fillér, $s$ már kỉ is van töltve a hivatalos igénylölap, amelytöl azután beindul a bürokrácia gépezete. Ám ez itt, a párizsi utcán - alacsony, összecsukható kisszéken üldögél, hordozható asztalán tinta, toll, papír - személyesebb természetủ levelek megírására vár. Ö ugyanis nem kéréseket fogalmaz hivatalos francia nyelven, hanem - finom mozdulatokkal jobbról balra haladva a papíron - arab kalligráfiával ír. Dolgozni szinte sohasem láttam." (Chambers 2001, 205) 
Hogyan értelmezzük ennek az idegennek a jelenléthez való jogát Európában? Miért az idegen? Idegen?

„Szandál van rajta, turbánt visel, s a csípős ősz miatt dzsellabába burkolózott. Szemben az új iskola - sokszínú, acélcsôves posztmodern építmény. Az utcai írástudó mozdíthatatlan méltósága kiemeli az idegen nyugtalanító jelenlétét. Tolla, a nyelv, amelyet beszél, egykorú az enyémmel. Elfordulhatnék, tettetve, hogy többé nem létezik, hogy csak furcsa maradványa az egykori bevándorlóknak, akik a „harmadik világból", a Maghreb-országokból érkeztek. Ám dönthetek úgy is, hogy jelenlétében egyszerủen az egzotikus és az archaikus betolakodását látom a modernitás világiasságába. De egy nyomot is érzékelek, nem csupán a látásomtól és értelmemtöl rejtező másik világét, hanem inkább egy nyelvét és történel mét, amely feleletet és felelösséget keres az enyémben. Bár minden jel szerint külföldi, világos, hogy ez az ő városa is $-s$ bizonyára jobban az övé, mint amennyire az 'enyém'. Mivel kénytelen vagyok átgondolni a modern tér összetett létrejöttét, amint az a Párizsnak nevezett kozmopolita helyen megszületik, érzékelem a másféleséget, integráns része ennek is és annak a modernségnek is, amelyet a magaménak vélek. Az arab irástudó, aki türelmesen ùidögél az utcasarkon egy modern nyugati városban, nem történel mi véletlen. Jelenléte, bár különálló, mégis elválaszthatatlanul összekapcsolódó, megzavarja és újrakonfigurálja saját történelmemet, és réssé alakítja 'identitásom' zárját, ahol olyannal találkozom, aki akaratomtól függetlenül létezik a világon." (Chambers 2001, 205-206)

Iain Chambers szerint az elismerés és a kulturális nyitottság jelentette kihívásnak más szubjektivitásra és nyelvre, az utazás és bizonytalanság étoszára, a kapcsolat etikájára van szüksége. „Nem... a birtoklás vágya, hanem a határtalané, amelyet inkább felkeltenek, semmint kielégítenek. Így lakni egy helyen, a visszafojtott történelmek helyén, amely lehetóvé teszi, hogy az enyém képviseltessék, ahol érzékelik a koherens identitás hallgatólagos kegyetlenségeit, és ezért olyan hely is, amely örökösen a nem otthonosat és a kísértetiest idézi, azt a törekvést jelenti, hogy a történelemböl a beteljesülés politikáját nyerjük ki, aminek a kimenetelét sohasem ismerjük elöre." (Chambers 2001, 207).

Chambershez hasonlóan Luce Irigaray (2002) megfontolásra javasolja, hogy „fontos lenne, hogy mostantól tudjuk, hogyan fonjuk össze az ugyanolyan és a másik szeretetét, az énhez és a valamivé váláshoz való hủséget a másikkal ... A kulturális termékenységet ... az odafigyelés és a keveredés hatásai eredményeznék ..." (Irigaray 2002, 141). Ez nehezen teljesíthetỏ kívánság, amelyhez bizonyos szellemiségre vagy tudatosságra van szükség, amelyhez csak kevesen folyamodnak, vagy csak kevesen tudják, hogyan kell hozzájuk folyamodni. Európa - akármit mondjon is a piac szabadságáról, az egyén elómenetelérỏl és a biztonságos határokról - jelenleg nincs abban a hangulatban, hogy lemásolja azt a fajta kulturális kísérletet, amelyet az Új Baloldal és az 1968-as diákmozgalmak indítottak el. Irigaray is egyetért azzal, hogy ez ,új program, amelyre nem vagyunk kiképezve” (Irigaray 2002,141 ), és elörelépésként nem tud sokkal többet ajánlani a vegyes családoknál.

Talán más szinten kellene reagálni a kihívásra: hivatalos nyilvánosságot adni a multikulturális politikai modellnek, amely ,elfogadja a kulturális sokszínüség realitását és kívánatos voltát" (Parekh 2000, 340), legyen az európai vagy transzeurópai, és elfogadja, hogy a haladó szellemü társadalom dialógusokból építkezik. „Legfóbb 
gondja és törekvése, hogy fenntartsa a párbeszédet, s olyan légkört tápláljon, amelyben hatékonyan halad elöre, kitágítja a határát a gondolkodás jelenlegi formáinak, közösen elfogadható elvek és intézmények egészét hozza létre" (Parekh 2000, 340). Ez az utolsó állítás kulcsfontosságú. A párbeszédre épülö multikulturalizmus megköveteli:

„bizonyos intézményes elöfeltételek meglétét; ilyenek például a szólásszabadság, kialakult eljárásrendek és alapvető etikai normák, részvételt biztosító nyilvános terek, egyenlö jogok, odafigyelő és a nyilvánosság elött elszámolni köteles hatalmi felépítmény, és a polgárok jogosultságai. Továbbá alapvető politikai erények is, úgy mint kölcsönös tisztelet és törödés, tolerancia, önmérséklet, hajlandóság ismeretlen gondolatvilág megismerésére, a különbözőség szeretete, új elképzelések iránti nyitottság, nyíltszívủ odafigyelés mások igényeire, a meggyőzés képessége és, hogy megoldatlan különbségekkel együtt tudjunk élni, szükségesek hozzá." (Parekh 2000, 340)

A másokkal való együttélés tehát megkívánja a közös jóváhagyást és kikényszerítést bizonyos szabályok, közös politikai értékek és kulturális szokások révén. Parekh (2000) szerint kétféle politikai filozófia járulhat ehhez hozzá: a liberalizmus, amely az egyén jogait és szabadságait, és a multikulturalizmus, amely a csoport szintú identitások és kultúrák jogait és szabadságait hangsúlyozza (ám a dialógus útján kialakult közös közösség kontextusában megfogalmazva, hogy elkerüljük a sokféleségnek azt a politikáját, amely csoport szintü elszigetelödéshez és türelmetlenséghez vezet). Egy új Európa-eszme támogathatná ezt a kettós filozófiát, s ezáltal kimozdíthatná a helyéről azt az uralkodó nacionalista elképzelésrendszert, amelynek nevében annyi sérelem éri mostanában a bevándorlókat és más idegeneket, akiket fajuk és etnikai hovatartozásuk miatt a gonosz megtestesítöiként bélyegeznek meg.

De ez még nem minden. A másokkal való együttélés/a mások révén történő átalakulás elvébe ágyazódik be a deleuzi értelmezés szerinti elkötelezettség egy inkább „séma-szerú”, mint „programadó” politika iránt, amely feltárja a „láthatatlant láthatóvá tevésben" rejlö lehetőségeket (Rajchman 1999, 42), és a jövőt az „újdonság kérdéseként" fogadja el (Rajchman 1999, 46). Az új Európában nem követik a jó élet elöre eldöntött eszméjét. Az alapeszme itt az agonizmus, vagy az egyenlő és hatalommal felruházott közösség demokratikus összeütközése mint a politikai elkötelezettség lényege és célja. Így a hangsúly áthelyeződik az európai lét megelölegezéséról az európaivá válásra, bízva abban, hogy a különbözöség mellé helyezése elindíthatja a „folyamatot, amelyben valami mássá, most még nem ismertté válunk" (Rajchman 1999, 48). Az empátia remélhetőleg abból fakad, hogy:

„van kötődés ahhoz, ami más, mint az adott ember, és a másikban meglévö különbség jelzéseiből nỏ ki; létezik kötổdés, amely a vitában a türelem, a kölcsönös függésben pedig a nagylelküség formájában mutatkozik meg, s nem arra törekszik, hogy egy nagyobb egység létrehozásával csökkentse a közte és a másik között meglévő távolságot. ... Az agonisztikus tiszteletnek ez az étosza a disszonánsan kölcsönös függőségek világában rendkívül fontos szerepet játszik a demokratikus politikák építményében: ... a távolság pátoszát az ellenvélemény, az együttmüködés és a hegemónia demokratikus viszonyaival ötvözi eggyé." (William Connolly 1993, 195 - idézi Schrift 2000, 156) 
A tanulmányban részletesen kifejtett okok miatt nincs garancia a „távolság pátoszára" az európai multikulturális elkötelezettség szabad piacán. Azonban amint a radikális demokrácia teoretikusai már felvetették, a nyilvános szféra, amely nyíltan elismeri a különbözőséghez való jogot, és böséges alkalmat teremt, hogy a kevésbé erösek igényt formálhassanak arra, s meg is kapják azt, ami jár nekik (a Parekh által felvetett, s fent hivatkozott szabályok segítségével), építóen tudja mederbe terelni az ellenséges politikát. Az így kialakított nyilvános európai szféra örömmel üdvözölné és támogatná „a demokratikus állampolgári létformák sokféleségét” (Mouffe 2000,73 ) és a „liberális demokrácia etikai-politikai elveihez - a szabadsághoz és egyenlöséghez - való közös ragaszkodást” (Mouffe 2000, 102) azért, hogy a kultúrpolitikát barátságos (agonizmus), nem pedig kibékíthetetlen ellenfelek közötti vetélkedésként lehessen formálni. Ami döntő, hogy ilyen politikai térben a következmények magának a részvételnek a folyamatához kötődnek, nem a minta-állampolgárhoz, a teleológiához, az európai lét kikristályosodott eszméjéhez.

Követve a kisebbség- és az al-politika Gilles Deleuze-i megkülönböztetését, mindez az ,al-politika” Európáját jelzi. Míg a kisebbség-politika gyakran az elismerés politikája, amely fiktív etnicitásra hagyatkozik, az ,al-politika” abból a feltevésböl indul ki, hogy ,bizonyos értelemben potenciálisan mindannyian a 'területi definíciók' elỏtti idegen 'semmiböl' származunk: mi, 'eljövendő emberek'." (Rajchman 1999, 50) A nemzeti (nacionalista) állam demokráciájának az európai integráció és a globalizáció által történö szétzilálása tökéletes lehetöséget nyújt a politika újrafogalmazásához, amely bevezeti ,a demokrácia fogalmába a kisebbség mindeddig képviselhetetlen ,idöszakát” (Rajchman 1999, 52). Az ígéret, hogy Európa az „eljövendö embereket" jelenti, ,alapvetôen hiányos; ez a többszörös diaszpórák posztkoloniális helye" (Werbner 1997, 263). A különbözöség és a különbözöség mindennapos megvitatásának politikája, nem pedig a feltételezett kozmopolitizmusra, az új fogyasztói identitásokra vagy hibriditásra épüló identitás feltételezett közössége.

\section{A közösség Európája}

Európa másik eszméjének e nyomon követései erőteljes szimbolikus értéket hordoznak, amelyek azonban - megfelelö gyakorlati lépések nélkül - nem találnak majd tömeges támogatottságra. A záró fejezetben azt a nézetemet fejtem ki, hogy egy kis, ám jelentós lépés Európa mint posztnacionális állam felé az alkotmányosan védett egyetemes jogok erösödése és kiterjesztése (az ottlakókra is, nem csak az állampolgárokra). Ezek azok a jogok, amelyekből az anyagi biztonság és előnyök, s rajtuk keresztül az Európa iránti ,alkotmányos hazafiság” lehetösége (Habermas 1998) és az agonisztikus találékonyságra képes közỏsség fakad.

A kiindulópont azon politikai, társadalmi és gazdasági jogok és normák - mint egyetemes jogok - felfelé irányuló harmonizációja, amelyek, az emberek vélekedése szerint, az európai állampolgárságból származó anyagi hasznot nyújtják. A jogok nyújtásában az egyes tagállamok differenciáltan különbséget tesznek saját vagy EU-s állampolgáraik és az állampolgársággal nem rendelkezők között. Politikájuk 
és magatartásuk más és más az EU-n kívülről jövő bevándorlással szemben. Eltérő jóléti (az egészségbiztosítástól kezdve az oktatáson át a segélyekig) és gazdasági (például minimálbér, vezetők és beosztottak viszonya, részmunkaidőben dolgozók biztosításai) jogokat nyứjtanak. Eltéröen bánnak az etnikai kisebbséggel (Hollandiában például mủködik az autonómia, Nagy-Britanniában a kulturális tolerancia, Franciaországban a nemzet-képbe való beolvadás). Nem meglepő tehát, hogy például a skandináv országok attól félnek, hogy az EU lecsapolja a magas hazai jóléti színvonalat, a briteket az aggasztja, hogy elvész politikai függetlenségük, az európai „dél” a hazai jóléti jogok erösítése eszközének tekinti az EU-t, míg a nemzeti többség mindenhol úgy tekint a bevándorlókra, mint akik tovább csapolják a forrásokat, ,elvesznek 'tőlünk', hogy adhassanak 'nekik'” (Markoff 1999, 32). Az EUszintü egyetemes jogok segíthetnek mérsékelni az ilyen irigységet; emellett a többszörös lojalitásúaknak jó okot adnak, hogy akarjanak az Európa-projekt részei lenni.

De visszatérve egy korábbi témára: kiket illetnének meg ezek a jogok? Csak az EU állampolgárait vagy azokat is, akik az EU-ban élnek, de nem EU-s állampolgárok? Ez az európai uniós jogról szóló szakirodalomban sokat vitatott és sokakat nyugtalanító kérdés. Én viszont hajlok arra, hogy Yasemin Soysallal (1994) értsek egyet: ha a bevándorlók jogait komolyan akarjuk venni, az állampolgársággal járó jogokat le kellene választani nemzeti alkotmányukról, és helyettük az EU-n belüli ott-tartózkodáson, nem EU-s állampolgárságon nyugvó, az egyéneknek szóló, felségterületeket átívelő jogokat kellene biztosítani. Rainer Bauböck (1995) hasonló álláspontot fejtegetett, amikor azt mondta, hogy minden külföldit megilletne minden politikai jog, amint megfelelnek a tartózkodással kapcsolatos bizonyos elöírásoknak. Más szóval: az ottlakókat az EU-n belül ugyanazon jogok illetnék meg, s a jogosultság már nem függne a nemzeti állampolgárságtól, amelyet hírhedten nehezen tudnak megszerezni a bevándorlók, nem csekély mértékben azért, mert sokkal több garanciát nyújt, mint a puszta állandó lakosi státus.

Ennek az ellentmondásos felvetésnek is megvannak a maga nehézségei, például a „kit engedjenek be Európába” erődítmény-szerü politikájának lehetősége, az állandó tartózkodási helyre vonatkozó szigorúbb szabályok, s a megfelelőség tolakodó ellenőrzése. Másrészt viszont az Európában állandó lakosként élök státusát egyenrangúsítja. Amint Gerald Delanty $(1997,299)$ megjegyzi:

„Ha az állandó lakosi státust az európai állampolgárság alapjaként átfogóbban alakítják $\mathrm{ki}$, a befogadás dimenzióját ki lehet terjeszteni. Az európai állampolgárság akkor nemcsak annak a körülbelül ötmillió EU-s állampolgárnak lehetne fontos, akik az EU más tagállamaiban élnek, hanem a mintegy tíz-tizenötmillió emigránsnak is."

A státus ilyen egyenrangúsítása, továbbá az a földrajzi és kulturális mobilitás is, amelyre ennek révén lehetőség nyílik, segíthet meglazítani a nemzethez füződő erős köteléket és hüséget, amelyet a jogoknak a nemzeti állampolgársággal történő öszszekapcsolása történelmileg erősített. Turner $(2000,30)$ reméli, hogy segít tudatosítani „olyan tagság ideológiáját, amely üdvözli a bizonytalanságot, hogy odatartozunk, ahol a 'végleges szókincsünk' sohasem végleges". Így a lojalitás és elkötelezettség a peripatetikus állampolgárság Európájában való utazás és mobilitás terméke lehet. 
Milyen jogok lehetnek a posztnemzeti európai modellben? Soysal (1994) nagyrészt emberi jogokra gondol, ám felvehető más is: politikai, gazdasági és szociális jogok is. Véleményem szerint ezek között a jóléti ellátáshoz való jogok kulcsfontosságúak abban a vonatkozásban, hogy azonnali anyagi elönyöket nyújtanak, $\mathrm{s}$ változást, hogy az oktatás, biztonságos lakóhely, egészségügyi ellátás stb. segítségével valakivé, másokká lehessünk. Gerald Delanty $(1997,293)$ érvelése szerint „ha Európa nem képes szupranacionális szinten reprodukálni a jóléti államot, ... nincs sok értelme értelmes európai állampolgárság mellett agitálni”. Érdekes azonban, hogy Delanty állításából hiányoznak a szavak: „,nagyon valószínủtlen perspektíva", s hajlok rá, hogy elfogadjam azt az álláspontot, miszerint az európai integráció egész történelme során a nemzeti kormányok féltékenyen örizték a jóléti döntések - mint a fiskális és elektorális irányítás eszközei - feletti hatalmukat. De lehet, hogy oly korban élünk, amikor - figyelembe véve az EU-n belüli fokozott mobilitást, a bevándorlók jelenlétét és a (leszálló ágban lévő) jóléti változatosságot - erősebb az európai jóléti állam tömegtámogatottsága.

Nem itt kell részletesen megvitatni, milyen jóléti jogokat kell közösen kezelni, s melyeket nemzeti szinten megtartani. Csak azt az alapálláspontot szeretném leszögezni, hogy sokat nyerhet a multikulturalizmus a transzeurópai egyetemes jogokra épiilő állampolgárság új európai modelljével. Az a benyomásom róla, hogy kevésbé megosztó, mint egy olyan kísérlet, amely megpróbálja rákényszeríteni az embereket, hogy egy elóre megadott Európa-eszméhez alkalmazkodjanak, és sokkal befogadóbb, mint a csoport alapon szétválasztott jogok és identitások véget nem éró elismerése.

\section{Zárszó}

Mostanában vannak jelei az eröteljesebb egyetemes jogokon nyugvó, közösség Európája iránti kormányközi érdeklődésnek. Az Alapvető Jogok Egyetemes Kartájának legújabb változata megerősítette az emberi jogok védelmét, s kiterjesztette az állampolgársággal nem rendelkezökre is. Ennek eredményeként a 21. cikk megtiltja a nem, börszín, etnikai és szociális eredet, nyelv és vallási meggyőződés szerinti megkülönböztetést. Nyújthatna néhány szabadságjogot, amelyekre az új Európa mint a hovatartozás és a valamivé válás új modelljének megteremtésére tett kísérlet terének létrehozásához van szükség. $\mathrm{Ez}$ azonban csupán kis lépés, amelyet a szabadság és az idegenek lehetőségeinek egyre gyakoribb EU-s és nemzeti szintủ megsértése közepette kell megtenni.

A közösség Európája nem lehet többé az erötlen nyilatkozatok Európája. Egyrészt, mert a faj-és idegengyülölet fenyegetése valós, félelmetes és kulturálisan agresszív. Gyengeségnek gondolom, hogy míg a tagállamok hanyatt-homlok rohantak, hogy közös erőfeszítéssel vonják szorosabbra EU-s határaikat azzal az indoklással, hogy a túlzott bevándorlás fenyegeti a biztonságot, és kimeríti a kevés számú jóléti forrást (bár a gazdasági menekülteket - ha fanyalogva is, de - befogadják), nem tettek határozott lépéseket a fajgyülölet megszüntetésére, sem arra, hogy ke- 
zelni tudják a kulturális fundamentalizmus egyéb formáit. Az 1980-as évek végétől kezdődően az Európa Parlament inspiráló kijelentésekben ítélte el az európai fajgyülöletet. Van néhány csodálatos, kötelező érvényü törvény a fajgyülölet ellen (például a 13. cikk), figyelemmel kísérik a faj- és idegengyủlölet megnyilvánulásait, s a Bizottság sok irányelvjavaslatot terjesztett elö a hontalanok és a harmadik világból jövők védelmére, akik már régóta állandó lakóhellyel rendelkeznek, és menekültek vagy menedékjogért folyamodnak. Ezekhez azonban csak ritkán folyamodnak, a cselekvést pedig a nemzeti kormányokra bízzák. Az utóbbiak, mint ahogyan vonakodnak feladni a jóléti ügyek irányítását, mindeddig még nem gyakoroltak akkora nyomást, amekkorát tudnának, hogy hatékony, európai uniós lépések történjenek, mivel ez meghagyja nekik a választást, hogy fajgyülölet ellenes nemzeti politikával engeszteljék ki az „otthoniakat”, más EU-s nemzeteket pedig befeketítsenek. Talán cinikus ez az értelmezés, de miért nem mozgósították a keresztény és felvilágosult Európa-eszmét olyan erőteljesen a fajgyülölet ellen, mint amennyire erőteljesen a nem-európai nemkívánatos elemek ellen mozgósították?

Fordította: Miskolczy Lászlóné - Timár Judit

\section{Jegyzet}

'Jelen cikk a 3. Nemzetközi Kritikai Geográfiai Konferencia (Békéscsaba, 2002. június 25-30.) plenáris vendégelőadásának magyar nyelvủ változata.

\section{Irodalom}

Agamben, G. (2000) Means Without Ends. University of Minnesota Press, Minneapolis.

Alibhai-Brown, Y. (1998) Islam and Euro-identity. - Demos Eurovisons: New Dimensions of European Integration. 13. 38-40. o.

Alibhai-Brown, Y. (2000) After Multiculturalism. The Foreign Policy Centre, London.

Bauböck, R. (ed.) (1995) From Aliens to Citizens. Avebury, Aldershot.

Bauman, Z. (1997) The making and unmaking of strangers. - Werbner, P.-Modood, T. (eds.) Debating Cultural Hybridity. Zed, London.

CEC (1987) Fresh Boost for Culture in the European Community. European Commission, Brussels.

CEC (1997a) Migration Statistics 1996. Eurostat, European Commission, Brussels.

CEC (1997b) Standard Eurobarometer 48, Public Opinion on the European Union. Autumn. European Commission, Brussels.

CEC (1998a) The Population of Selected European Countries by Country of Birth. Eurostat (Statistics in Focus) 10. European Commission, Brussels.

CEC (1998b) Standard Eurobarometer 49, Public Opinion on the European Union. Autumn. European Commission, Brussels.

CEC (1998c) Standard Eurobarometer 50, Public Opinion on the European Union. Autumn. European Commission, Brussels.

CEC (2000a) Standard Eurobarometer 53, Public Opinion on the European Union. Spring. European Commission, Brussels.

CEC (2000b) Standard Eurobarometer 54, Public Opinion on the European Union. Autumn. European Commission, Brussels.

Chambers, I. (2001) Culture After Humanism. Routledge, London.

Cohen, R. (1998) Who needs an island? - New Formations, 33. 11-37. o.

Delanty, G. (1995) Inventing Europe. Macmillan, London. 
Delanty, G. (1997) Models of citizenship: defining European identity and citizenship. - Citizenship Studies. 3, 285-303. o.

Derrida, J. (2001) On Cosmopolitansim and Forgiveness. Routledge, London.

Friedman, J. (1997) Global crises, the struggle for cultural identity and intellectual porkbarrelling: cosmopolitans versus locals, ethnics and nationals in an era of de- hegemonisation. - Modood, T.Werbner, P. (eds.) The Politics of Multiculturalism. Zed, London.

Habermas, J. (1998) The Inclusion of the Other: Studies in Political Theory. MIT Press, Mass, Cambridge. Heffernan, M. (1998) The Meaning of Europe. Arnold, London.

Ifekwunigwe, J. (1999) Scattered Belongings. Routledge, London.

Irigaray, L. (2002) Between East and Wes. Columbia University Press, New York.

Joseph, M. (1999) Nomadic Identities. University of Minnesota Press, Minneapolis.

Kristeva, J. (2001) Europhilia, europhobia. - Lotringer, S.-Cohen, S. (eds.) French Theory in America. Routledge, London. 33-46. o.

Leonard, M. (1998b) Europe's legitimacy gap. - Demos. Eurovisons: New Dimensions of European Integration. 13. 46-47. 0 .

Leonard, M. (1998a) Making Europe: The Search for European Identity. Demos, London.

Maffesoli, M. (1996) Time of the Tribes: The Decline of Individualism in Mass Society. Sage, London.

Malik, K. (1998) Race, pluralism and the meaning of difference. - New Formations. 33. 125-135. o.

Markoff, J. (1999) Our 'common European home' - but who owns the house? - Smith, D.-Wright, S. (eds.) Whose Europe? Blackwell, Oxford. 21-47. o.

Melotti, U. (1997) International migration in Europe: social projects and political cultures. - Modood, T.Werbner, P. (eds.), The Politics of Multiculturalism. Zed, London. 73-92. 0.

Melucci, A. (1996) The Playing self. University Press, Cambridge.

Melucci, A. (1997) Identity and difference in a globalized world. - Modood, T.-Werbner, P. (eds.) The Politics of Multiculturalism. Zed, London. 58-69. o.

Modood, T. (1997) Introduction: the politics of multiculturalism in the new Europe. - Modood, T.Werbner, P. (eds.) The Politics of Multiculturalism. Zed, London. 1-26. o.

Mouffe, C. (2000) The democratic paradox. Verso, London, New York.

Nilsen, B.F.-Stubb, C-G. (eds.) (1998) The European Union. Readings on the Theory and Practice of European Integration. L. Rienner, Boulder, CO.

Parekh, B. (2000) Rethinking Multiculturalism. Palgrave, Basingstoke.

Pieterse, J. (1999) Europe travelling light: Europeanization and globalization. - The European Legacy. 3. 3-17. o.

Pieterse, J. (2001) Hybridity, so what? The anti-hybridity backlash and the riddles of recognition. Theory. Culture and Society. 18. 219-245. o.

Pred, A. (2000) Even in Sweden. University of California Press, Berkeley.

Prodi, R. (1999) Un' idea dell' Europe. II Mulino, Bologna.

Rajchman, J. (1999) Diagrams and diagnosis. - Grosz, E. (ed.) Becomings. Cornell University Press, Ithaca. 42-54. o.

Ristilammi, P-M. (1996) Alterity in modern Sweden. - Arvastson, G.-Lindqvist, M. (eds.) The Story of Progress. Acta Universitatis Upsaliensis, Uppsala.

Schrift, A. (2000) Nietzche, Foucault, Deleuze, and the subject of radical democracy, - Angelak. 2. 151-161. o.

Shore, C. (1998) The myth of a Euro-identity - Demos. Eurovisons: New Dimensions of European Integration. 13, 48-50. 0 .

Soysal, Y. (1994) Limits to Citizenship. Chicago University Press, Chicago.

Spinner-Halev, J. (1999) Cultural pluralism and partial citizenship. - Joppke, C.-Lukes, S. (eds.) Multicultural Questions. Oxford University Press, Oxford.

Stolcke, V. (1995) Talking culture: new boundaries, new rhetorics of exclusion in Europe. - Current Anthropology. 1. 1-13. o.

Turner, B.S. (2000) Liberal citizenship and cosmopolitan virtue. - Vandenberg, A. (ed.) Citizenship and Democracy in a Global Era. Macmillan Press, Basingstoke. 18-32. o.

Werbner, P. (1996) Fun spaces: on identity and social empowerment among British Pakistanis. - Theory, Culture and Society. 4. 53-79. o.

Werbner, P. (1997) Afterword: writing multiculturalism and politics in the new Europe. - Modood, T.Werbner, P. (eds.) The Politics of Multiculturalism. Zed, London. 261-267. o. 


\title{
MULTIETHNICITY AND THE IDEA OF EUROPE
}

\begin{abstract}
ASH AMIN
This paper explores the meaning and relevance of the 'Idea of Europe' in the context of a multicultural continent that increasingly draws on the presence and practices of people from non-European backgrounds. It argues that in a Europe of extraordinary cultural interchange and immigration from all corners of the world, the classical Idea of Europe is strikingly exclusionary and backward looking - a poor motif for the future. The Idea continues to appeal to the Christian-Enlightenment-Romanticist heritage of European nations, to mobilise support for European integration.

The paper develops an alternative Idea of Europe, one based on an evolving ethos of belonging in a Europe that is a migrant space, to replace an ethos based on the enduring cultural values of a body of people called Europeans. It makes the case for unity around egalitarian political principles such as a commons protected by appropriate EU-level rights, that can both support and bind cultural pluralism and difference. It also proposes democratic vitalism as Europe's core political project, that is the idea of becoming European, on the basis of the vibrant clash of an empowered multiple public. No myth of origin, no myth of destination, only the commitment to a plural demos.
\end{abstract}

